\title{
AKRUAL
}

Jurnal Akuntansi

http://fe.unesa.ac.id/ojs/index.php/akrl

\section{PENGARUH PEMBIAYAAN JUAL BELI, PEMBIAYAAN BAGI HASIL DAN INTELLECTUAL CAPITAL TERHADAP KINERJA KEUANGAN BANK SYARIAH}

\author{
Achmad Syaiful Nizar \\ MahasiswaJurusanAkuntansi Fakultas EkonomiUniversitas Negeri Surabaya \\ Email: nizar.syaiful27@gmail.com \\ Moch. Khoirul Anwar \\ JurusanEkonomi IslamFakultas EkonomiUniversitasNegeri Surabaya \\ Email: khoirulanwar@unesa.ac.id
}

\begin{abstract}
This research aims to examine the effect of trade financing, profit sharing financing and intellectual capital as measured with islamic Bank-Value Added Intellectual Coeficient (iBVAIC) towards financial performance as measured with Return On Asset (ROA) of islamic bank. The population in this study is an Islamic commercial bank during the period 20112014, of all populations there are 9 Islamic commercial bank that have meet the criteria for the research samples. Data used in this research are annual financial statements published on official website of Islamic commercial bank. The analysis technique used in this research is multiple linear regression analysis. These result shows that trade financing don't affect of financial performance, profit sharing financing don't affect of financial performance and intellectual capital affect of financial performance.
\end{abstract}

Keywords: Financing, Intellectual Capital, Financial Performance and Islamic Bank

\begin{abstract}
Abstrak
Penelitian ini bertujuan untuk menguji pengaruh pembiayaan jual beli, pembiayaan bagi hasil dan intellectual capital yang diukur dengan islamic Bank-Value Added Intellectual Coeficient (iB-VAIC) terhadap kinerja keuangan yang diukur dengan Return On Asset (ROA) di bank syariah. Populasi dalam penelitian ini adalah bank umum syariah selama periode 2011-2014, dari semua populasi ada 9 bank umum syariah yang mempunyai kriteria sampel penelitian. Data yang digunakan dalam penelitian ini adalah laporan keuangan tahunan yang diterbitkan di website resmi bank umum syariah. Teknik analisis yang digunakan dalam penelitian ini adalah analisis regresi linier berganda. Hasilnya menunjukkan bahwa pembiayaan jual beli tidak mempengaruhi kinerja keuangan, pembiayaan bagi hasil tidak mempengaruhi kinerja keuangan dan modal intelektual mempengaruhi kinerja keuangan.
\end{abstract}

Kata kunci : Pembiayaan, Intellectual capital, Kinerja keuangan, dan Bank syariah 


\section{PENDAHULUAN}

Lahirnya undang-undang nomor 21 tahun 2008 tentang perbankan syariah merupakan salah satu faktor yang menyebabkan perkembangan perbankan syariah di Indonesia semakin pesat. Bertambah banyaknya jumlah bank dengan berbagai macam bentuk pelayanan dan produk yang diberikan dapat menciptakan permasalahan pada bank syariah itu sendiri. Menurut Ibrahim et al (2003) permasalahan yang paling pokok yaitu bagaimana kualitas dari kinerja bank syariah. Menurut Dendawijaya (2009:20) sebagai lembaga yang penting dalam perekonomian, bank syariah membutuhkan adanya pengawasan kinerja keuangan yang baik oleh regulator perbankan. Indikator untuk menilai kinerja keuangan suatu bank adalah melihat tingkat profitabilitasnya. Profitabilitas dapat diukur dengan rasio keuangan yaitu Return on Asset (ROA).

Tabel 1 memaparkan bahwa total return on asset pada Bank Umum Syariah (BUS) dan Unit Usaha Syariah (UUS) selama dua tahun terakhir yaitu tahun 2013 dan 2014 mengalami penurunan. Hal ini menunjukkan bahwa kinerja keuangan dari bank syariah mengalami penurunan. Menurut Purwoko dan Sudiyatno (2013) salah satu faktor yang mempengaruhi kinerja keuangan bank yaitu bagaiamana suatu bank mengelola asetnya. Pengelolaan aset pada bank syariah dilakukan melalui penyaluran pembiayaan.

\section{Tabel 1.Komposisi Pembiayaan Yang Diberikan Dan Rasio Keuangan Bank Umum Syariah Dan Unit Usaha Syariah}

\begin{tabular}{crcccc}
$\begin{array}{c}\text { Tahun } \\
\text { ROA } \\
(\%)\end{array}$ & $\begin{array}{c}\text { Jual Beli } \\
\text { (Dalam Miliar } \\
\text { Rupiah) }\end{array}$ & $\begin{array}{c}\text { Bagi Hasil } \\
\text { (Dalam Miliar } \\
\text { Rupiah) }\end{array}$ & $\begin{array}{c}\text { Sewa } \\
\text { (Dalam Miliar } \\
\text { Rupiah) }\end{array}$ & $\begin{array}{c}\text { Qard } \\
\text { (Dalam Miliar } \\
\text { Rupiah) }\end{array}$ \\
\hline 2010 & 1,67 & 37.855 & 23.255 & 2.341 & 4.731 \\
2011 & 1,79 & 56.691 & 29.189 & 3.839 & 12.937 \\
2012 & 2,14 & 88.380 & 39.690 & 7.345 & 12.090 \\
2013 & 2 & 111.147 & 53.196 & 10.481 & 8.995 \\
2014 & 0,85 & 118.004 & 63.741 & 11.620 & 5.965 \\
\hline
\end{tabular}

Sumber : Statistik Perbankan Syariah, 2015, diolah

Perkembangan pembiayaan jual beli dan pembiayaan bagi hasil selama tahun 2010 sampai tahun 2014 mengalami peningkatan seperti yang dijelaskan pada tabel 1. Namun, peningkatan pembiayaan jual beli dan pembiayaan bagi hasil seharusnya memberikan pendapatan yang besar pula sehingga laba yang diperoleh juga akan meningkat, kenyataannya tingkat laba yang ditunjukkan oleh ROA tahun 2013 dan tahun 2014 justru menurun.

Selain mengelola aset yang berupa pembiayaan, bank syariah juga harus memanfaatkan aset lain seperti intellectual capital. Intellectual capital adalah aset tidak berwujud yang dimiliki dan digunakan perusahaan untuk menghasilkan manfaat dan meningkatkan kesejahteraan (Suhendah, 2012). Menurut Ifada dan Hapsari (2012) secara umum intellectual capital dibagi menjadi tiga komponen diantaranya human capital, structural capital, dan customer capital. 
Tabel 2.Kinerja Intellectual Capital Bank Umum Syariah

\begin{tabular}{|c|c|c|c|c|}
\hline Tahun & 2011 & 2012 & 2013 & 2014 \\
\hline Rata-Rata & 2,45 & 3,04 & 2,48 & 2,23 \\
\hline
\end{tabular}

Sumber :Laporan Keuangan Bank Syariah2011-2014, diolah

Tabel 2 menunjukkan rata-rata kinerja intellectual capital bank umum syariah tahun 2011 sampai 2014 mengalami fluktuatif. Namun, jika dilihat rata-rata kinerja intellectual capital bank syariah tahun 2011 sampai 2014 tidak ada yang mendapatkan skor dibawah 1,5. Hal ini menunjukkan bahwa kinerja dan pengelolaan intellectual capital di bank syariah masih baik. Melihat kinerja intellectual capital yang baik pada bank syariah, seharusnya bank syariah juga memiliki kinerja keuangan yang baik. Kenyataannya justru kinerja keuangan bank syariah mengalami penurunan pada tahun 2013 dan 2014, kenyaataan tersebut tidak sesuai dengan teori dan data. Bedasarkan latar belakang di atas dan adanya perbedaan teori dengan data maka penulis membuat sebuah rumusan masalah yaitu apakah pembiayaan jual beli, pembiayaan bagi hasil dan intellectual capital berpengaruh terhadap kinerja keuangan bank syariah.

\section{KAJIAN PUSTAKA \\ Stewardship Theory}

Teori stewardship adalah teori yang dicetuskan oleh Donaldson dan Davis tahun 1989. Teori stewardship menjelaskan situasi dimana manajer sebagai steward tidaklah termotivasi oleh tujuan-tujuan individu tetapi lebih ditujukan untuk kepentingan principal atau kepentingan bersama. Teori ini juga memiliki asumsi bahwa kepentingan personal antara steward dan principal dapat diselaraskan melalui pencapaian tujuan bersama, ketika kepentingan steward dan principal tidak sama, steward akan menjunjung tinggi nilai kebersamaan sehingga tujuan bersama dapat dicapai (Raharjo, 2007). Stewardship teori dapat dipahami dalam pembiayaan lembaga perbankan syariah. Bank syariah sebagai principal mempercayakan nasabah sebagai steward untuk mengelola dana akan mengembalikan dana yang telah diberikan oleh bank syariah (Riyadi dan Yulianto, 2014). Kepercayaan yang diberikan oleh bank syariah kepada nasabah, mempunyai harapan agar nasabah bertindak sesuai dengan tujuan bersama yang dibuat diawal akad pembiayaan sehingga bank syariah ataupun nasabah dapat memperoleh keuntungan. Keuntungan yang diperoleh dari pembiayaan yang diberikan akan menjadi pendapatan dan akan meningkatkan laba bank syariah sehingga kinerja keuangan dari bank syariah akan meningkat.

\section{Resource Based Theory (RBT)}

Resource based theory dipelopori oleh Penrose (1959), yang mengemukakan bahwa sumber daya perusahaan bersifat heterogen dan memiliki karakter khusus dan unik bagi setiap perusahaan (Astuti dan Sabeni, 2005). Resource based theory menyatakan bahwa perusahaan memiliki sumber daya yang dapat menjadikan perusahaan memiliki keungulan yang bersaing dan mampu mengarahkan perusahaan untuk memiliki kinerja jangka panjang yang baik. Resources yang berharga dan langka dapat diarahkan untuk menciptakan keunggulan bersaing, sehingga resource yang dimiliki mampu bertahan lama dan tidak mudah ditiru, ditransfer atau digantikan (Ulum, 2015: 20).

Kondisi sumber daya yang unggul dalam suatu perusahaan dapat membuat penerapan berbagai strategi bisnis berjalan dengan baik. Pengelolaan sumber daya yang baik dalam hal ini berupa intellectual capital yaitu human capital, structural capital, dan customer capital dapat menciptakan keunggulan kompetitif bagi perusahaan yang nantinya dapat menciptakan value added yang berguna untuk perusahaan sehingga dapat berpengaruh terhadap kinerja keuangan, pertumbuhan perusahaan dan nilai pasar pada perusahaan tersebut (Herdayanto dan Nasir, 2013). 


\section{Bank Syariah}

Menurut undang-undang nomor 21 tahun 2008 pasal 1 ayat 7 bank syariah adalah bank yang menjalankan kegiatan usahanya berdasarkan prinsip syariah dan menurut jenisnya terdiri atas bank umum syariah dan bank pembiayaan rakyat syariah. Bank Syariah dalam operasionalnya mempunyai beragam produk-produk yang ditawarkan kepada nasabah atau masyarkat, tentunya produk-produk yang ditawarkan sesuai dengan prinsip-prinsip syariah, antara lain GiroiB, TabunganiB, DepositoiB, Jasa iB dan Pembiayaan iB.

\section{Pembiayaan Bedasarkan Prinsip Jual Beli}

Menurut Muhamad (2006:93)pembiayaan jual beli adalah transaksi jual beli antara bank dan nasabah dimana harga, jumlah, dan waktu penyerahan barang sudah ditentukan diawal akad. Pembiayaan jual beli terdiri dari akad murabahah, akad salam dan akad istihna'. Pembiayaan jual beli dapat diukur dengan cara sebagai berikut Rachman dan Rochmanika (2012):

Ln (pembiayaan murabahah + pembiayaan istihna' + pembiayaan salam)

\section{Pembiayaan Berdasarkan Prinsip Bagi Hasil}

Pembiayaan bagi hasil adalah akad kerjasama antara bank sebagai pemilik modal dengan nasabah sebagai pengelola modal untuk memperoleh keuntungan dan membagi keuntungan yang diperoleh berdasarkan kesepakatan atau nisbah yang disepakati (Nurhayati, 2009:198). Pembiayaan bagi hasil terdiri dari akad musyarakah dan akad mudharabah. Pembiayaan jual beli dapat diukur dengan cara sebagai berikut Rachman dan Rochmanika (2012):

$$
\text { Ln (pembiayaan musyarakah + pembiayaan mudharabah) }
$$

\section{Intellectual Capital}

Menurut Ifada dan Hapsari (2012) modal intelektual merupakan modal jangka panjang yang terdiri dari human capital, structural capital, dan customer capital. Human capital (HC) merupakan kualitas sumber daya manusia yang dimiliki perusahaan. Structural capital (SC) meliputi teknologi informasi, struktur organisasi, strategi, budaya kerja yang baik, serta kemampuan perusahaan dalam memenuhi seluruh rutinitas perusahaan. Customer capital (CC) adalah hubungan yang baik dan berkelanjutan antara perusahaan dengan para mitranya, seperti distributor, pemasok, pelanggan, karyawan, masyarakat, pemerintah, dan sebagainya.

\section{Islamic Banking-ValueAdded Intellectual Coefficient(iB-VAIC)}

VAIC dikonstruksikan oleh Pulic (1998) untuk menilai kinerja intellectual capital pada perusahaan konvensional (non syariah). Akun-akun yang digunakan dalam menghitung intellectual capital dengan VAIC adalah akun-akun yang lazim pada perusahaan konvensional. Sejauh ini, belum ada indikator (sejenis VAIC) yang dapat digunakan menilai kinerja intellectual capital perbankan syariah (Ulum 2015: 117). iB-VAIC yang dikonstruksikan oleh ulum (2013) merupakan alat ukur yang cocok untuk menilai kinerja intellectual capital karena bedasarkan pada akun-akun keuangan bank syariah di Indonesia. Langkah pertama untuk memperoleh nilai iB-VAIC adalah menghitung iB-Value Added (iBVA) yaitu selisih antara nilai OUT dan nilai IN, dimana OUT diperoleh dari total pendapatan bersih kegiatan syariah (pendapatan operasi utama + total pendapatan operasional lainya) dikurangi hak pihak ketiga atas bagi hasil dana syirkah temporer kemudian ditambah total pendapatan non operasional. Setelah nilai OUT didapatkan, kemudian menghitung nilai IN, yaitu beban usaha atau operasional dan beban non operasional kecuali beban personalia atau karyawan. Tahap kedua dalam mengitung iB-VAIC yaitu dengan menghitung Value Added Capital Employed (iB-VACA). iB-VACA adalah indikator untuk iB-value added yang 
diciptakan oleh satu unit dari dana yang tersedia. Rasio ini menunjukkan kontribusi yang dibuat oleh setiap unit dari capital employment (CE) atau dana yang tersedia terhadap iBvalue added (iB-VA) perusahaan.

Langkah selanjutnya yaitu menghitung iB-Value Added Human Capital (iB-VAHU). iB-VAHU menunjukkan berapa banyak iB-Value Added (iB-VA) dapat dihasilkan dengan dana yang dikeluarkan untuk tenaga kerja. Rasio ini menunjukkan kontribusi yang dibuat oleh setiap rupiah yang diinvestasikan dalam human capital terhadap iB-value added organisasi. Langkah keempat yaitu menghitung iB-Structural Capital Value Added (iBSTVA). Rasio ini mengukur jumlah Structural Capital (SC) yang dibutuhkan untuk menghasilkan satu rupiah dari iB-VA dan merupakan indikasi bagaimana keberhasilan structural capital (SC) dalam penciptaan nilai. Structural capital (SC) adalah selisih antara iB-Value Added (iB-VA) dengan Human Capital (HC). Tahap terakhir dalam perhitungan Islamic Bank Value Added Intellectual Coefficient (iB-VAIC) yaitu dengan menjumlahkan iBVACA, iB-VAHU, dan iB-STVA.

\section{Kinerja Keuangan}

Kinerja keuangan bank adalah gambaran kondisi keuangan bank pada suatu periode tertentu baik menyangkut aspek penghimpunan atau penyaluran dana yang biasanya diukur dengan indikator kecukupan modal, likuiditas dan profitabilitas (Jumingan, 2005:239). Profitabilitas menunjukkan tingkat keberhasilan perusahaan mengeloala aset yang dimiliki untuk memperoleh laba. Alat analisis yang sering digunakan untuk mengukur tingkat profitabilitas adalah mengunakan rasio keuangan yaitu return on asset.

$$
\text { Return OnAssets }=\frac{\text { Laba sebelum pajak }}{\text { Total Aset }} \times 100 \%
$$

Bedasarkan latar belakang masalah dan kajian pustaka yang sudah diuraikan, maka dapat dirumuskana hipotesis sebagai berikut:

$H_{1}$ : Pembiayaan jual beli berpengaruh terhadap kinerja keuangan

$\mathrm{H}_{2}$ : Pembiayaan bagi hasil berpengaruh terhadap kinerja keuangan

$\mathrm{H}_{3}$ : Intellectual capital berpengaruh terhadap kinerja keuangan

\section{METODE PENELITIAN}

Populasi yang digunakan dalam penelitian ini adalah bank umum syariah yang terdaftar dalam Bank Indonesia selama periode penelitian. Penelitian ini menggunakan teknik purposive sampling. Berdasarkan kriteria penentuan sampel yang telah ditentukan, terdapat sembilan bank umum syariah yang menjadi sampel penelitian. Data yang digunakan dalam penelitian ini adalah jenis data sekunder, yaitu berupa laporan keuangan tahunan yang dipublikasikan oleh bank umum syariah di Indonesia periode 2011-2014. Variabel dependen yang digunakan dalam penelitian ini adalah kinerja keuangan dan variabel independen yaitu pembiayaan jual beli, pembiayaan bagi hasil dan intellectual capital. Teknik analisis data yang digunakan yaitu statistik deskriptif, analisis regresi berganda dan uji asumsi klasik. 
HASIL DAN PEMBAHASAN

Statistik Deskriptif

Tabel 3. Hasil Analisis Deskriptif

Descriptive Statistics

\begin{tabular}{lrrrrr}
\hline & N & \multicolumn{1}{c}{ Minimum } & \multicolumn{1}{c}{ Maximum } & \multicolumn{1}{c}{ Mean } & Std. Deviation \\
\hline PJB & 36 & 26.54 & 31.15 & 28.8953 & 1.35785 \\
PBH & 36 & 0 & 30.69 & 25.6153 & 8.02147 \\
iB-VAIC & 36 & 1.35 & 4.51 & 2.5517 & 0.90966 \\
ROA & 36 & 0.08 & 3.81 & 1.4497 & 1.05041 \\
Valid N (listwise) & 36 & & & & \\
\hline
\end{tabular}

Sumber: Data olah SPSS

Tabel 3 menampilkan bahwa rata-rata nilai PJB adalah 28.8953. Nilai PJB terendah adalah 26.54 yaitu dimiliki oleh PT. Bank Central Asia Syariah pada 2011. Sedangkan nilai PJB tertinggi adalah 31.15 yaitu dimiliki oleh PT. Bank Syariah Mandiri pada 2014. Variabel independen PBH memiliki nilai rata-rata sebesar 25.6153. Nilai PBH terendah adalah 0.00 yaitu dimiliki oleh PT. May bank Syariah tahun 2013, 2012 dan 2011. Sedangkan nilai PBH tertinggi adalah 30.69 yaitu dimiliki oleh PT. Bank Muamalat Indonesia pada 2014. Nilai rata-rata iB-VAIC seluruh perusahaan perbankan yang menjadi sampel yaitu sebesar 2.5517. Nilai iB-VAIC terendah adalah 1.35 yaitu dimiliki oleh PT. Bank Rakyat Indonesia Syariah pada 2014. Sedangkan nilai iB-VAIC tertinggi yaitu dimiliki oleh May Bank Syariah tahun 2014 sebesar 4.51.

Variabel dependen dalam penelitian ini yaitu ROA yang memiliki nilai rata-rata sebesar 1.4497. Untuk nilai ROA terendah yaitu sebesar 0.08 dimiliki oleh PT. Bank Rakyat Indonesia Syariah pada 2014. Sedangkan untuk nilai ROA tertinggi yaitu sebesar 3.81 dimiliki oleh PT. Bank Mega Syariah pada 2012.

Uji Normalitas

Hasil Uji Kolmogorov-Smirnov pada tabel 4 menunjukkan nilai signifikansi Asymp. Sig. (2-tailed) sebesar 0.996 artinya nilai signifikansi di atas 0,05 maka variabel pengganggu atau residual berdistribusi secara normal.

Tabel 4. Hasil Uji Kolmogorov - Smirnov One-Sample Kolmogorov-Smirnov Test

\begin{tabular}{llr}
\hline \multicolumn{3}{c}{ Unstandardized Residual } \\
\hline $\mathrm{N}$ & Mean & 36 \\
Normal & Std. Deviation & 0.40476801 \\
Parameters ${ }^{\mathrm{a}, \mathrm{b}}$ & Absolute & 0.068 \\
& Positive & 0.068 \\
Most Extreme & Negative & -0.053 \\
Differences & 0.407 \\
Kolmogorov-Smirnov Z & 0.996 \\
Asymp. Sig. (2-tailed)
\end{tabular}




\section{Uji Mutikolinieritas}

Hasil uji multikolinieritas menunjukkan bahwa tidak ada variabel independen yang memiliki nilai tolerance kurang dari 0,1 dan nilai VIF juga menunjukan tidak ada yang lebih dari 10. Jadi dapat disimpulkan bahwa tidak ada multikolinieritas antar variabel independen dalam model regresi.

Tabel 5. Hasil Uji Multikolinieritas Coefficients $^{\text {a }}$

\begin{tabular}{|c|c|c|c|c|c|c|c|}
\hline \multirow[t]{2}{*}{ Model } & \multicolumn{2}{|c|}{$\begin{array}{c}\text { Unstandardized } \\
\text { Coefficients }\end{array}$} & \multirow{2}{*}{$\begin{array}{c}\text { Standardized } \\
\text { Coefficients } \\
\text { Beta }\end{array}$} & \multirow[t]{2}{*}{$\bar{T}$} & \multirow[t]{2}{*}{ Sig. } & \multicolumn{2}{|c|}{$\begin{array}{l}\text { Collinearity } \\
\text { Statistics }\end{array}$} \\
\hline & B & $\begin{array}{l}\text { Std. } \\
\text { Error }\end{array}$ & & & & Гoleranci & VIF \\
\hline (Constant) & .200 & 1.587 & & .126 & .900 & & \\
\hline PJB & -.059 & .056 & -.076 & -1.040 & .306 & .878 & 1.140 \\
\hline${ }^{1} \mathrm{PBH}$ & .007 & .012 & .052 & .580 & .566 & .582 & 1.717 \\
\hline iB-VAIC & 1.084 & .098 & .939 & 11.073 & .000 & .645 & 1.550 \\
\hline
\end{tabular}

a. Dependent Variable: ROA

Sumber: Data olah SPSS

\section{Uji Autokorelasi}

Hasil pengujian uji autokorelasi pada tabel 6 dapat dilihat besarnya nilai DurbinWatson adalah 1.959 maka setelah melihat tabel Durbin-Watson didapatkan dL=1.2953 dan $\mathrm{dU}=1.6539$. Hasil analisis menunjukkan nilai Durbin-Watson telah berada diantara 1.6539 (dU) dan 2.3461 (4-1.6539), sehingga dapat disimpulkan model regresi terbebas dari masalah autokorelasi.

Tabel 6. Hasil Uji Autokorelasi dengan Durbin-Watson Model Summary ${ }^{\mathrm{b}}$

\begin{tabular}{lcrrrr}
\hline Model & $\mathrm{R}$ & $\begin{array}{c}\mathrm{R} \\
\text { Square }\end{array}$ & $\begin{array}{c}\text { Adjusted R } \\
\text { Square }\end{array}$ & $\begin{array}{c}\text { Std. Error of the } \\
\text { Estimate }\end{array}$ & $\begin{array}{l}\text { Durbin- } \\
\text { Watson }\end{array}$ \\
\hline 1 & $.923^{\mathrm{a}}$ & .852 & .838 & .42332 & 1.959 \\
\hline
\end{tabular}

a. Predictors: (Constant), iB-VAIC, PJB, PBH

b. Dependent Variable: ROA

Sumber: Data olah SPSS

\section{Uji Heterokedastisitas}

Tabel 7. Hasil Uji Heteroskedastisitas dengan Uji Glejser Coefficients $^{\mathrm{a}}$

\begin{tabular}{|c|c|c|c|c|}
\hline \multicolumn{2}{|c|}{$\begin{array}{c}\text { Unstandardized } \\
\text { Coefficients }\end{array}$} & \multirow{2}{*}{$\begin{array}{c}\text { Standardized } \\
\text { Coefficients } \\
\text { Beta }\end{array}$} & \multirow[t]{2}{*}{$\mathrm{t}$} & \multirow[t]{2}{*}{ Sig. } \\
\hline $\mathrm{B}$ & Std. Error & & & \\
\hline .212 & .943 & & .225 & .823 \\
\hline-.001 & .033 & -.007 & -.038 & .970 \\
\hline$-7.664 \mathrm{E}-005$ & .007 & -.002 & -.011 & .991 \\
\hline .056 & .058 & .208 & .964 & .342 \\
\hline
\end{tabular}

a. Dependent Variable: ABS_RES1

Sumber: data diolah SPSS 
Hasil output Uji Glejser dengan jelas menunjukkan bahwa model regeresi tidak mengandung heterokedastisitas. Hal ini terlihat dari probabilitas semua variabel independen menunjukkan nilai probabilitas signifikansinya diatas 0,05 atau $5 \%$.

\section{Koefisien Determinasi}

Berdasarkan uji asumsi klasik yang sudah dilakukan, bisa disimpulkan bahwa secara umum data layak untuk dilanjutkan ke tahap pengujian hipotesis untuk mengetahui pengaruh dan tingkat signifikan dengan Uji t dan Uji F. Sebelum masuk ke tahap uji hipotesis dilakukan pengukuran ketepatan fungsi regresi sampel dalam menaksir nilai aktual yang dapat diukur dari nilai koefisien determinasi. Berikut adalah hasil uji koefisien determinasi yang sudah dilakukan:

Tabel 8. Hasil Koefisien Determinasi Model Summary

\begin{tabular}{|c|c|c|c|c|c|}
\hline \multirow[t]{2}{*}{ Model } & & $\mathrm{R}$ & R Square & Adjusted R Square & Std. Error of the E \\
\hline & 1 & $.923^{\mathrm{a}}$ & 0.852 & 0.838 & \\
\hline
\end{tabular}

Sumber: data diolah SPSS

Tabel 8 memaparkan seberapa jauh kemampuan model dalam menerangkan variasi variabel dependen dengan melihat nilai Adjusted $R$ square. Nilai Adjusted $R$ Square adalah $83,8 \%$, artinya variasi nilai ROA dapat dijelaskan oleh variasi dari ke tiga variabel independen yaitu PJB, PBH dan iB-VAIC. Sedangkan sisanya $(100 \%-83,8 \%=16,2 \%)$ dijelaskan oleh sebab-sebab lain di luar model.

Uji Signifikansi Simultan (Uji Statistik F)

Tabel 9. Hasil Uji Satatistik F

ANOVA $^{\mathrm{a}}$

\begin{tabular}{lrrrrr}
\hline Model & $\begin{array}{l}\text { Sum of } \\
\text { Squares }\end{array}$ & Df & Mean Square & F & Sig. \\
\hline Regression & 32.883 & 3 & 10.961 & 61.167 & $.000^{\mathrm{b}}$ \\
1 Residual & 5.734 & 32 & .179 & & \\
Total & 38.617 & 35 & & & \\
\hline
\end{tabular}

a. Dependent Variable: ROA

b. Predictors: (Constant),iB-VAIC, PJB, PBH

Sumber: data diolah SPSS

Hasil uji ANOVA atau uji $\mathrm{F}$ menunjukkan nilai probabilitas yang diperoleh sebesar 0,000, nilai probabilitas tersebut jauh lebih kecil dari 0,05 maka model regresi dapat digunakan untuk memprediksi nilai ROA dan dapat dikatakan bahwa PJB, PBH dan iBVAIC secara bersama-sama berpengaruh terhadap nilai ROA.

\section{Uji Signifikansi Parameter Individual (Uji Statistik t)}

Bedasarkan hasil output uji statistik $\mathrm{t}$ menunjukkan bahwa dari ketiga variabel independen yang dimasukan ke dalam model regresi, variabel PJB dan PBH tidak signifikan. Hal ini dapat dilihat dari probabilitas signifikansi untuk PJB sebesar 0.306 dan PBH sebesar 0.566, dimana keduanya jauh di atas 0.05 . Sedangkan variabel iB-VAIC signifikan, dengan nilai probabilitas signifikansi sebesar 0.000 
Tabel 10. Hasil Uji Satatistik t

Coefficients $^{\mathrm{a}}$

\begin{tabular}{lcccrr}
\hline Model & \multicolumn{2}{c}{$\begin{array}{c}\text { Unstandardized } \\
\text { Coefficients }\end{array}$} & $\begin{array}{c}\text { Standardized } \\
\text { Coefficients }\end{array}$ & T & Sig. \\
& \multicolumn{1}{c}{ B } & Std. Error & Beta & & \\
\hline (Constant) & .200 & 1.587 & & .126 & .900 \\
1 PJB & -.059 & .056 & -.076 & -1.040 & .306 \\
PBH & .007 & .012 & .052 & .580 & .566 \\
iB-VAIC & 1.084 & .098 & .939 & 11.073 & .000 \\
\hline
\end{tabular}

Sumber: data diolah SPSS

\section{Pembahasan}

\section{$\mathrm{H}_{1}$ : Pengaruh pembiayaan jual beli terhadap kinerja keuangan bank syariah}

Hipotesis penelitian yang pertama diuji untuk mengetahui pengaruh pembiayaan jual beli terhadap kinerja keuangan bank syariah. Hasil penelitian ini menunjukkan bahwa pembiayaan jual beli terbukti tidak berpengaruh terhadap kinerja keuangan keuangan yang diukur dengan return on asset (ROA) bank syariah. Hasil analisis dengan menggunakan uji t, nilai signifikan $t$ hitung untuk pembiayaan jual beli sebesar 0,306 dengan koefisien regresi variabel ini sebesar -1,040 sehingga dapat disimpulkan bahwa pembiayaan jual beli secara parsial tidak berpengaruh terhadap kinerja keuangan yang diukur dengan return on asset $(0,306>0,05)$.

Bedasarkan teori stewardship, bank syariah yang mempercayakan dananya melalui penyaluran pembiayaan untuk dikelola dan akan dikembalikan oleh nasabah sesuai dengan kesepakatan yang dibuat. Namun bisa saja nasabah menyalahgunakan kepercayaan yang diberikan oleh bank syariah, sehingga belum tentu pembiayaan jual beli yang disalurkan oleh bank pada nasabah akan dikembalikan sesuai perjanjian yang telah disepakati bersama antara bank dengan nasabah. Hal ini menyebabkan pembiayaan jual beli tidak berpengaruh terhadap kinerja keuangan yang diukur dengan return on asset (ROA), ini terbukti dari bank umum syariah yang memiliki tingkat penyaluran pembiayaan jual beli tertinggi yaitu Bank Syariah Mandiri pada 2014 sebesar 33 triliun. Laporan tahunan Bank Syariah Mandiri tahun 2014 menyatakan bahwa pembiayaan yang disalurkan masih didominasi oleh akad murabahah yaitu mencapai $68,62 \%$ dan jumlah pembiayaan jual beli meningkat dari 33,2 triliun pada 2013 menjadi 33,7 triliun pada 2014. Kenaikan jumlah pembiayaan murabahah ini seharusnya akan memberikan kenaikan pendapatan dan juga laba Bank Syariah Mandiri. Namun, di sisi lain beban usaha dari Bank Syariah Mandiri juga mengalami peningkatan sebesar 9,87\% dan kenaikan risiko pembiayaan (NPF) yang pada 2013 sebesar 2,29\% menjadi 4,29\% pada 2014 mendekati tingkat maksimum persyaratan Bank Indonesia yaitu sebesar 5\% (NPF-net), kondisi tersebut menyebabkan laba Syariah Mandiri tidak mengalami peningkatan. Hal ini terbukti nilai ROA Bank Syariah Mandiri sebesar 0,17\% masih setara dengan bank lain yang menjadi sampel, meskipun Bank Syariah Mandiri memiliki nilai pembiayaan jual beli tertinggi. Inilah yang menyebabkan tingginya pembiayaan jual beli yang disalurkan oleh Bank Syariah Mandiri tidak memengaruhi nilai ROA yang diperoleh.

Kondisi sebaliknya juga berlaku untuk bank umum syariah yang memiliki pembiayaan jual beli terendah yakni Bank Central Asia Syariah pada 2011 yang menunjukkan nilai sebesar 336 miliar. Pembiayaan jual beli dengan akad murabahah sebenarnya adalah pembiayaan yang mendominasi bagi Bank Central Asia Syariah tahun 2011 yaitu sebesar 54,9\%. Namun, jika dibandingkan dengan tingkat pembiayaan jual beli bank umum syariah yang menjadi sampel, Bank Central Asia Syariah menempati posisi terendah seperti yang diungkapkan dalam laporan tahunan Bank Central Asia Syariah tahun 
2011. Rendahnya tingkat pembiayaan jual beli disebabkan Bank Central Asia Syariah baru beroperasi pada bulan April 2010 sehingga belum semua masyarakat mengenal Bank Central Asia Syariah, khususnya pada produk pembiayaan jual beli. Meskipun memiliki nilai pembiayaan jual beli terendah, Bank Central Asia Syariah memiliki nilai ROA sebesar $0,90 \%$, dimana nilai tersebut lebih tinggi dibandingkan nilai ROA bank yang menjadi sampel yang memiliki tingkat pembiayaan jual beli lebih tinggi. Hal ini dikarenakan pada tahun 2011 Bank Central Asia Syariah mampu mengelola pembiayaan jual beli secara efektif sehingga tingkat risiko pembiayaan (NPF) hanya sebesar 0,2\%, angka tersebut masih jauh dibawah tingkat maksimum persyaratan Bank Indonesia yaitu sebesar 5\% (NPF-net).

\section{$\mathrm{H}_{2}$ : Pengaruh pembiayaan bagi hasil terhadap kinerja keuangan}

Hipotesis penelitian yang kedua diuji untuk mengetahui pengaruh pembiayaan bagi hasil terhadap kinerja keuangan keuangan yang diukur dengan return on asset (ROA) bank syariah. Hasil penelitian ini menunjukkan bahwa pembiayaan bagi hasil terbukti tidak berpengaruh terhadap kinerja keuangan bank syariah. Ini dibuktikan dengan hasil statistik pembiayaan bagi hasil yang memberikan koefisien parameter 0,007 dengan tingkat signifikansi 0,566 yang berarti tidak berpengaruh $(0,556>0,05)$.

Hasil penelitian ini terbukti sama bahwa pembiayaan bagi hasil yang disalurkan oleh bank syariah tidak berpengaruh terhadap nilai ROA bank syariah yang terjadi pada fenomena 2013-2014. Tahun 2012-2013, nilai ROA bank syariah mengalami penurunan dari $2,14 \%$ pada 2013 menjadi $2 \%$ pada 2014, sedangkan nilai pembiayaan bagi hasil yang disalurkan mengalami peningkatan dari 39 triliun pada 2013 menjadi 53 triliun pada 2014. Kondisi yang sama juga terjadi pada 2013 ke 2014 dimana nilai ROA bank syariah mengalami penurunan dari $2 \%$ pada 2013 menjadi 0,85\% pada 2014. Namun di sisi lain, penyaluran pembiayaan bagi hasil mengalami peningkatan dari 53 triliun pada 2013 menjadi 63 Triliun pada 2014 triliun. Tinggi rendahnya pembiayaan bagi hasil yang disalurkan dianggap tidak memengaruhi nilai ROA bank syariah.

Tidak berpengaruhnya pembiayaan bagi hasil terhadap kinerja keuangan yang diukur dengan return on asset dapat disebabkan oleh kepercayaan yang disalahgunakan oleh nasabah. Berdasarkan teori stewardship, bank syariah mempercayakan dananya kepada nasabah melalui penyaluran pembiayaan untuk dikelola dan nantinya akan dikembalikan sesuai kesepakatan yang dibuat. Namun, terdapat kemungkinan jika nasabah akan menyalahgunakan kepercayaan dari pihak bank syariah, sehingga belum tentu pembiayaan bagi hasil yang disalurkan oleh bank pada nasabah akan dikembalikan sesuai perjanjian yang telah disepakati bersama antara bank dengan nasabah.

Return on asset (ROA) adalah rasio yang digunakan untuk mengukur kemampuan manajemen dalam mendapatkan laba. Laba bank syariah diperoleh dari total pendapatan dikurangi dengan hak pihak ketiga atas bagi hasil dana syirkah temporer dan total beban. Bank syariah yang memiliki penyaluran pembiayaan jual beli berpotensi memiliki laba yang tinggi, dikarenakan pendapatan dari margin keuntungan pembiayaan jual beli juga akan tinggi sehingga return on asset (ROA) juga akan meningkat. Namun, pendapatan yang tinggi tersebut tidak akan berpengaruh terhadap laba bank syariah apabila hak pihak ketiga atas bagi hasil dana syirkah temporer dan total beban juga meningkat sehingga nilai return on asset (ROA) juga tidak akan terpengaruh.

Pembiayaan bagi hasil adalah akad kerjasama antara pihak bank sebagai pemilik modal dengan nasabah sebagai pengelola modal untuk mendapatkan keuntungan dan membagi keuntungan yang diperoleh berdasarkan kesepakatan atau nisbah yang telah disepakati. Apabila terdapat kerugian akan ditanggung oleh pemilik modal selama kerugian itu bukan akibat kelalaian si pengelola. Namun, bila kerugiaan disebabkan karena kesengajaan pengelola maka pengelola wajib menanggungnya. Menurut Reinissa (2015) keuntungan atau pendapatan bagi hasil dari pembiayaan mudharabah bersifat tidak pasti 
dikarenakan pendapatan bagi hasil ditentukan sesuai dengan omset usaha yang diperoleh. Oleh sebab itu, perhitungan pendapatan senantiasa berubah sesuai dengan pencapaian omset usaha, sehingga menyebabkan pembiayaan bagi hasil tidak berpengaruh signifikan terhadap ROA (return on assets).

Rahman dan Rochmanika (2012) menambahkan bahwa pengelolaan pembiayaan bagi hasil lebih sulit dibandingkan dengan pengeloaan jual beli sebab bank syariah sebagai pemilik modal harus mengawasi dan mengevaluasi usaha yang telah diberikan pembiayaan agar pihak pengelola menjalankan usahanya dengan baik karena apabila terjadi terjadi kerugian pihak bank juga ikut menanggungnya. Hal ini menyebabkan biaya yang dikeluarkan dalam pengelolaan pembiayaan bagi hasil juga lebih tinggi dari pada jenis pembiayaan lainnya. Pendapatan bagi hasil bank umum syariah yang diperoleh dari penyaluran pembiayaan bagi hasil kemungkinan masih belum secara optimal diperoleh sehingga belum mampu mengimbangi biaya-biaya yang dikeluarkan. Oleh karena itu, sumbangan pendapatan bagi hasil yang diperoleh dari penyaluran pembiayaan bagi hasil masih belum mampu mengoptimalkan kemampuan bank syariah dalam menghasilkan laba.

Nilai pembiayaan bagi hasil yang paling tinggi di antara perusahaan sampel yaitu Bank Muamalat Indonesia pada 2014 yang mencapai 21 Triliun. Pembiayaan bagi hasil ini merupakan pembiayaan yang mendominasi bagi Bank Muamalat Indonesia. Laporan tahunan 2014 Bank Muamalat Indonesia menyampaikan bahwa terjadi kenaikan pendapatan yang berasal dari pembiayaan bagi hasil sebesar 435,20 miliar atau 22,27\% dari tahun sebelumya. Walaupun terjadi kenaikan pendapatan dari pembiayaan bagi hasil, namun laba usaha dari Bank Muamalat Indonesia justru mengalami penurunan. Penurunan ini disebabkan karena beban margin dan juga beban usaha meningkat sebesar 54,97\% dan 16,18\% dari tahun sebelumnya.Sedangkan untuk nilai ROA dari Bank Muamalat Indonesia memliki nilai yang sama dengan nilai ROA dari bank lain yang menjadi sampel yaitu 0,17\%, meskipun Bank Muamalat Indonesia memiliki tingkat pembiayaan bagi hasil tertingi pada bank yang menjadi sampel. Hal ini menunjukkan bahwa tinggi rendahnya pembiayaan bagi hasil tidak memengaruhi nilai ROA bank tersebut.

Salah satu bank yang memiliki nilai pembiayaan bagi hasil terkecil yakni Maybank Syariah yaitu sebesar 0 pada tahun 2013, 2012 dan 2011. Laporan tahunan Maybank Syariah menunjukkan pada 2011 sampai 2013 produk yang ditawarkan khususnya produk pembiayaan hanya terdapat produk dengan akad jual beli maka pada periode tersebut tidak ada pembiayaan bagi hasil yang disalurkan, maka pendapatan dari pembiayaan bagi hasil juga tidak ada. Di sisi lain nilai ROA pada tahun 2011-2013 tidaklah sama pada periode tersebut, bahkan nilai ROA Maybank Syariah pada 2011-2013 merupakan nilai ROA tertinggi pada tahun tersebut pada bank yang menjadi sampel, walaupun Maybank Syariah tidak memiliki pendapatan dari pembiayaan bagi hasil.

Jadi secara garis besar yang memengaruhi kinerja keuangan bank syariah adalah kualitas dari pembiayaan yang diberikan atau pembiayaan bermasalah (non performing financing). Walaupun jumlah pembiayaan jual beli dan pembiayaan bagi hasil yang disalurkan tinggi, jika tingkat non performing financing dari pembiayaan tersebut juga tinggi maka pendapatan dari bank syariah akan turun sehingga kinerja keuangan juga tidak akan terpengaruh. Selain itu, biaya operasional yang dikeluarkan oleh bank syariah juga memengaruhi kinerja keuangan. Jumlah pembiayaan jual beli dan pembiayaan bagi hasil yang tinggi akan menghasilkan pendapatan yang tinggi, namun bila jumlah biaya operasional juga ikut meningkat maka pendapatan tersebut tidak akan memengaruhi kinerja keuangan sebab pendapatan tersebut akan digunakan untuk menutupi jumlah biaya yang meningkat.

\section{$\mathrm{H}_{3}$ : Pengaruh intellectual capital terhadap kinerja keuangan bank syariah}


Berdasarkan hasil analisis dengan menggunakan uji t, niIai signifikansi t hitung untuk intellectual capital sebesar 0,000 yang lebih kecil dari 0,05 sedangkan koefisien regresi variabel ini sebesar 11,073 sehingga dapat disimpukan bahwa intellectual capital secara parsial berpengaruh terhadap kinerja keuangan. Hal ini menunjukkan bahwa intellectual capital dapat memengaruhi kinerja keuangan perusahaan, karena intellectual capital mampu menciptakan keunggulan kompetitif bagi perusahaan sehingga perusahaan mampu beradaptasi terhadap perubahan yang terjadi dilingkungan bisnisnya, dengan demikian kinerja keuangan perusahaan dapat terjaga dengan baik (Yunita, 2012).

Berpengaruhnya intellectual capital terhadap kinerja keuangan bank syariah dalam penelitian ini mendukung konsep resources based theory (RBT) yang menjelaskan bahwa perusahaan memiliki sumber daya yang dapat menjadikan perusahaan memiliki keunggulan yang bersaing dan mampu mengarahkan perusahaan untuk memiliki kinerja jangka panjang yang baik. Perusahaan yang memiliki sumber daya dalam hal ini intellectual capital yang baik akan memiliki kinerja keuangan yang baik.

Hasil penelitian ini menunjukkan bahwa semakin efisien perusahaan mengelola aset dalam hal ini intellectual capital (human capital, structural capital dan customer capital) yang dimiliki perusahaan akan memberikan hasil yang meningkat yang ditunjukkan dari peningkatan kinerja keuangan perusahaan. Pengelolaan komponen dari intellectual capital sangat penting bagi perusahaan karena intellectual capital dapat berperan penting dalam menciptakan nilai tambah dan berkontribusi dalam peningkatan kinerja keuangan perusahaan.

Menurut Wijaya (2012) human capital menjadi salah satu komponen dari intellectual capital yang sangat menentukan tingkat efisiensi dari intellectual capital. Human capital merupakan kekuatan intellectual yang bersumber dari sumber daya manusia yang dimiliki perusahaan yaitu pengetahuan, kompetensi dan ketrampilan dari karyawan. Human capital dapat menciptakan nilai tambah yang akan meningkatkan kinerja keuangan perusahaan jika perusahaan mempunyai sumber daya manusia yang berkualitas dan mampu memanfaatkannya dengan baik.

Sebagai contoh, Bank Mega Syariah menyadari bahwa sumber daya manusia merupakan ujung tombak kemajuan dan pertumbuhan bisnis perusahaaan, untuk itulah Bank Mega Syariah berkomitmen meningkatkan kualitas sumber daya manusia yang dimilikinya melalui beberapa program strategis. Pertama, melalui Management Develompment Program yaitu program pendidikan yang didesain khusus untuk menghasilkan calon-calon pemimpin junior yang potensial yang dimiliki perusahaan selama delapan bulan dengan model pendidikan komprehensif mengenai perbankan seperti in class training, simulasi dan praktek lapangan, on the job training dan project assignment. Kedua, melalui Talent Pool dan Succession Planyang bertujuan untuk mempertahankan pegawai-pegawai terbaik dan mempersiapkan para kader yang berkualitas dan memiliki kapabilitas kepemimpinan yang baik untuk menduduki posisi penting diperusahaan. Selain itu, bagi pegawai baru diberikan program induction training, yang meliputi pendidikan dasar utama mengenai perbankan syariah, nilai-nilai syariah, pengenalan akuntansi dasar, compliance, risk dan good corporate governance.

Contoh lain, Bank Muamalat Indonesia berupaya meningkatkan profesionalisme dan kinerja usaha sumber daya manusia yang mereka miliki melalui pemakaian Human Capital Information System (HCIS) atau yang dikenal sebagai Muamalat Human Power (MHP). Muamalat Human Power menjadi penting kerena dalam aplikasi tersebut terdapat fungsi administrasi kepegawaian, online training, media sosialisasi terkait peraturan perusahaan yang dapat diakses secara langsung di komputer kerja karyawan masing-masing. Muamalat Human Power juga terbukti dapat meningkatkan efektifitas sistem promosi, pelatihan, pendidikan dan penilaian kinerja kerja karyawan serta terbukti efektif khususnya dalam 
meningkatkan kualitas proses-proses administrasi kepegawaian pada Bank Muamalat Indonesia.

Komponen intellectual capital lainnya yaitu structural capital juga tidak kalah pentingnya bagi perusahaan, menurut Saryanti (2011) structural capital dapat mendukung human capital untuk menghasilkan kinerja yang baik dan dapat mempermudah operasional usaha perusahaan. Sebagai contoh, Bank Syariah Mandiri yaitu mengembangkan program management information system, dengan sistem tersebut dapat menjembatani informasi dan pengawasan di kantor pusat, regional, area dan cabang. Selain mengembangkan management information system, Bank Syariah Mandiri juga mengembangkan core banking dan sistem pembayaran melalui $E D C$, hal ini betujuan untuk menambah dan mempermudah transaksi yang dilakukan oleh nasabah. Manfaat lain dari structural capital, tercermin dari inovasi produk yang dimiliki oleh Bank Syariah Mandiri yakni BSM e-money.

Contoh lain dari upaya optimalisasi structural capital ditunjukkan oleh Bank Muamalat Indonesia yang dilakukan lewat e-Chanel, dengan e-Chanel Bank Muamalat Indonesia memiliki layanan Payment Point Online Bank (PPOB). Layanan ini memungkinkan masyarakat untuk melakukan pembayaran berbagai jenis tagihan seperti listrik, air, premi asuransi, dan telekomunikasi secara tunai melalui agen-agen Muamalat terdekat tanpa harus datang ke loket pembayaran resmi penyedia jasa. Layanan e-Chanel yang dimiliki Bank Muamalat Indonesia juga dapat digunakan untuk pembayaran zakat, infaq dan shadaqah sehingga memudahkan nasabah dalam menyalurkan kewajiban sosialnya. Selain itu untuk mempermudah perusahaan dalam rangka mendistribusikan produk dan layanan yang dimiliki. Bank Muamalat Indonesia terus berinvestasi pada penambahan unit Mobile Branch Muamalat (MBM). MBM berfungsi sebagai outlet pelayanan yang berpindahpindah (mobile) yang dapat menangani kebutuhan nasabah untuk pembukaan rekening, penyetoran uang tunai dan pelayanan transaksi perbankan lainya. MBM juga dilengkapi dengan ATM Muamalat yang terhubung online melalui koneksi jaringan GPRS sehingga dapat menjangkau lokasi dengan akses terbatas dan dapat dioperasikan di luar jam kerja kantor cabang. Upaya lain juga dilakukan oleh Bank Muamalat Indonesia untuk mempermudah menjual produk dan menambah transaksi yang dilakukan oleh nasabah. Pertama melalui Internet Banking (IB Muamalat), dimana Bank Muamalat Indonesia menambah fitur belanja online pada Internet Banking (IB Muamalat). Fitur belanja online ini berkerja sama dengan sejumlah merchant online yang sudah dikenal oleh konsumen di Indonesia dan dengan Debit Online nasabah penguna IB Muamalat dapat dengan mudah dan aman melakukan transaksi pembelian dan pembayaran di merchant-merchanttersebut. Kedua, Bank Muamalat juga melakukan pengembangan layanan Mobile Banking (MB Muamalat) lewat platform Android, iOS dan BlackBerry, dengan Mobile Bankingnasabah dapat melakukan transaksi dengan mudah sesuai dengan keperluan.

Customer capital merupakan hubungan baik perusahaan dengan para mitranya seperti nasabah.Menurut Soetedjo dan Mursida (2014) perusahaan yang memberikan pelayanan kepada customer dan merespon kritik dan saran yang diberikan oleh customer dengan baik dapat meningkatkan profitabilitas perusahaan sehingga dapat menjadikan kinerja keuangan perusahaan menjadi baik. Sebagai contoh, Bank Syariah Mandiri melalui laporan tahunannya meyakini bahwa pelanggan merupakan salah satu pemangku kepentingan yang mempunyai peran sentral dalam menjamin keberlangsungan usaha, sehingga merupakan partner utama dalam mengembangkan usaha. Oleh karenanya bagi Bank Syariah Mandiri, pemenuhan segala kebutuhan terhadap produk layanan dilakukan dengan memprioritaskan pemenuhan terhadap harapan para pelanggan. Upaya untuk menunjukkan komitmen tersebut, Bank Syariah Mandiri memiliki beberapa langkah layanan strategis. Pertama, memberikan jaminan perlindungan simpanan nasabah.Bank Syariah Mandiri tidak hanya menjual produk perbankan yang aman namun juga memberikan perlindungan maksimal kepada nasabah, 
melalui jaminan perlindungan atas uang yang disimpan oleh nasabah lewat lembaga penjamin simpanan. Kedua, peningkatan kualitas layanan nasabah. Demi memenuhi kepuasan nasabah terhadap jasa perbankan, Bank Syariah Mandiri tidak henti-hentinya melakukan berbagai upaya meningkatkan kualitas layanan mulai dari SDM frontliner, tata ruang kantor cabang/pembantu/kas, pengembangan aplikasi pencatatan pengaduan nasabah (complaint management system), program pelibatan nasabah seperti sahabat BSM, BSM fantasi (hadiah langsung), gebyar (berkumpul bersama nasabah dengan berbagai macam kegiatan), iBvaganza (program edukasi perbankan syaiah kepada nasabah) dan priority gathering (silaturahim nasabah). Ketiga, memberikan kemudahan akses informasi dan jaringan layanan perbankan.Usaha yang dilakukan Bank Syariah Mandiri untuk memberikan kemudahan akses informasi yaitu dengan menyediakan informasi lewat situs internet dan jejaring sosial (facebook dan twitter). Sedangkan untuk mengoptimalkan pelayanan kepada nasabah, Bank Syariah Mandiri memberikan kemudahan fasilitas dengan menambah jumlah jaringan kantor dan jaringan ATM. Keempat, menyediakan pusat pengaduan nasabah. Bank Syariah Mandiri memiliki kebijakan bahwa penyelesaian setiap keluhan nasabah yang disampaikan menjadi prioritas utama yang harus segera ditindaklanjuti. Hal ini karena ada keterkaitan keluhan dengan loyalitas nasabah terhadap produk layanan yang digunakan. Oleh karena itu Bank Syariah Mandiri membentuk bagian service quality management \& customercare dengan tujuan memberikan respon yang cepat atas pengaduan yang masuk, memonitoring pengaduan nasabah dan memberikan penyelesaian secara bijak.

Contoh lain dari bank syariah yang fokus terhadap customer capital yaitu Bank Muamalat Indonesia. Bank Muamalat Indonesia mempunyai pandangan bahwa dalam industri perbankan saat ini, dengan pilihan produk dan layanan yang dapat dikatakan sama atau mirip, kualitas pelayanan kepada nasabah menjadi salah satu faktor pembeda yang sangat penting guna memenangkan persaingan. Untuk itu Bank Muamalat Indonesia melakukan upaya-upaya yang terarah dan bekesinambungan untuk meningkatkan kompetensi personil teller, customers service, dan satpam sebagai ujung tombak pelayanan yang paling banyak berinteraksi langsung dengan nasabah melalui pemberian pembekalan dan pelatihan. Setiap personil customers service pada kantor pelayanan sudah dilengkapi dengan fasilitas $e$ sales kit yang menggantikan materi cetak/brosur produk dan layanan. Fasilitas e-sales kit memudahkan nasabah atau calon nasabah dalam menerima penjelasan mengenai fitur, manfaat dan keunggulan dari berbagai produk layanan Bank Muamalat melalui layar monitor PC yang ada di meja personil customers service. Peningkatan kualitas pelayanan juga diupayakan melalui program tahunan Service Champion, melalui program ini Bank Muamalat memberikan penghargaan untuk personil teller, customers service dan satpam yang dinilai memperlihatkan kinerja terbaik selama satu tahun dari sisi pelayanan dengan harapan dapat memotivasi seluruh personil yang terlibat langsung dalam aktivitas pelayanan nasabah untuk terus meningkatkan kualitas kerjanya masing-masing. Strategi yang dijalankan Bank Muamalat untuk memberikan kenyamanan layanan dan kemudahan fasilitas bagi nasabah yaitu dengan menambah jaringan kantor dan jaringan ATM. Selain memberikan kemudahan bagi nasabah, strategi menambah jaringan ATM juga mempunyai dampak positif bagi perusahaan yakni meningkatnya pendapatan imbal jasa dari transaksi nasabah di ATM yaitu sebesar 34,61 miliar dibandingkan tahun sebelumnya yang hanya sebesar 25,68 miliar.

Bank yang memiliki nilai Islamic Bank-Value Added Intellectual Coefficient (iBVAIC) tinggi juga diikuti dengan nilai return on asset (ROA) yang tinggi yaitu dimiliki oleh Maybank Syariah pada 2014. Sebaliknya, Bank Rakyat Indonesia Syariah yang memiliki nilai islamic Bank-Value Added Intellectual Coefficient (iB-VAIC) terendah pada 2014 juga memiliki nilai return on asset (ROA) paling rendah diantara bank yang menjadi sampel.' 


\section{SIMPULAN DAN SARAN}

Pembiayaan jual beli dan pembiayaan bagi hasil tidak berpengaruh terhadap kinerja keuangan bank syariah karena pembiayaan jual beli dan pembiayaan bagi hasil yang disalurkan tinggi, namun jika manajemen tidak bisa mengelola pembiayaan dan biaya operasional terhadap pendapatan operasional dengan baik maka tingginya pembiayaan yang disalurkan tidak akan mempengaruhi kinerja keuangan. Intellectual capital berpengaruh terhadap kinerja keuangan bank syariah. Berpengaruhnya intellectual capital terhadap kinerja keuangan dikarenakan intellectual capital mampu menciptakan keunggulan kompetitif bagi bank syariah sehingga bank syariah mampu bersaing dan beradaptasi terhadap perubahan yang terjadi dilingkungan bisnisnya, dengan demikian kinerja keuangan bank syariah dapat meningkat dan terjaga dengan baik. Berdasarkan hasil penelitian terdapat beberapa saran untuk perbaikan dan evaluasi bagi peneliti selanjutnya dengan topik yang sama, yaitu penelitian selanjutnya lebih fokus terhadap intellectual capital dengan menggunakan alat ukur iB-VAIC, khususnya pada penelitian yang mengunakan objek berprinsip syariah. Peneliti selanjutnya bisa menganalisis pengaruh komponen iB-VAIC terhadap kinerja keuangan. Mengingat penelitian pembiayaan jual beli dan pembiayaan bagi hasilmembuktikan tidak berpengaruh pada kinerja keuangan yang diukur dari aspek earning, maka untuk penelitian selanjutnya diharapkan menggunakan aspek lain untuk mengukur kinerja bank syariah sesuai metode RGEC yakni dari aspek risiko (risk profile), aspek tata kelola perusahaan yang baik (good corporate governance) dan aspek permodalan (capital). 


\section{DAFTAR PUSTAKA}

Astuti, P.D. dan A. Sabeni. 2005. "Hubungan Intellectual Capital dan BusinessPerformance”. Proceeding SNA VII. Solo. pp. 694-707

Dendawijaya, Lukman. 2009. Manajemen Perbankan. Jakarta: Ghalia Indonesia.

Davis, James dan Donalson, Lex. 1997. "Toward a Stewardship Theory of Management." Academy of Management Review". Vol. 22, No. 1, page 22-47, 1997.

Ghozali, Imam. 2006. Aplikasi Analisis Multivariate dengan Program SPSS. Badan Penerbit Universitas Diponegoro. Semarang.

Herdayanto, I dan Nasir, M. 2013.“ Pengaruh Intellectual Capitalpada financial performance perusahaan studi empiris pada perusahaan infrastruktur, utilitas dan transportasi yang terdaftar di bursa efek indonesia tahun 2009-2011". Journal Of Accounting, Vol. 2 (3), Hal. 1-10.

Ibrahimetal.(2003).“AlternativeDisclosureandPerformanceMeasuresforIslamic Bank".www.iium.edu.my.diakses tanggal 21 November 2014.

Ifada, Luluk Muhimatul dan Hapsari, Harida. 2012. "Pengaruh Intellectual Capital Terhadap Kinerja Keuangan Perusahaan Publik (Non Keuangan) di Indonesia”. Jurnal Reviw Akuntansi dan Keuangan. Vol.2 No. 1, Pp 181-194.

Jumingan. 2008. Analisis Laporan Keuangan. Jakarta: PT Bumi Aksara.

Muhamad. 2005. Teknik Perhitungan Bagi Hasil Dan Profit Margin Pada Bank Syariah. Yogyakarta : UII Press

Nurhayati, Sri Dan Wasilah. 2009. Akuntansi Syariah Di Indonesia, Edisi 2. Jakarta : Salemba Empat

Otoritas JasaKeuangan (OJK). 2015. Laporan Statistik Perbankan Syariah. Outlook OJK.Diperolehtanggal 30 September 2015 dari www.ojk.co.id.

Pulic,A.1998."Measuring theperformanceofintellectualpotentialin knowledge economy".Diperolehtanggal 30 September 2015 dari www.vaic-on.net.

Purwoko, Didik dan Sudiyatno, Bambang. 2013. "Faktor-Faktor Yang Mempengaruhi Kinerja Bank (Studi Empirik Pada Industri Perbankan Di Bursa Efek Indonesia)".Jurnal Bisnis dan Ekonomi (JBE), Vol. 20, Hal. 25 - 39.

Raharjo, Eko. 2007. "Teori Agensi dan Teori Stewardship dalam Perspektif Akuntansi". Jurnal Fokus Ekonomi, Vol. 2, No. 1, Hal: 37-46

Rahman,F.Auliadan Rochmanika,Ridha.2011. "PengaruhPembiayaanJualBeli, Pembiayaan Bagi Hasil, dan Rasio NonPerforming Financing terhadap Profitabilitas Bank Umum SyariahdiIndonesia”.Jurnal Akuntansi Dan Keuangan. Vol. 2 : hal: 1-14

Reinissa. 2015. "Pengaruh Pembiayaan Mudharabah, Musyarakah, Dan MurabahahTerhadap Profitabilitas Bank Syariah Mandiri, Tbk". Jurnal Akuntansi Dan Keuangan. Vol. 2 : hal: 1-16

Riyadi, Slamet dan Yulianto, Agung. 2014. "Pengaruh Pembiayaan bagi Hasil, Pembiayaan Jual Beli, Financing to Deposit Ratio (FDR) dan Non Performing Financing (NPF) terhadap Profitabilitas Bank Umum Syariah di Indonesia". Accounting Analysis Journal. Vol. 3 (4), Hal: 466-474

Saryanti, E. 2011. "Pengaruh Intellectual Capital Terhadap Kinerja Keuangan Perusahaan Perbankan Yang Terdaftar Di Bursa Efek Indonesia Tahun 2007-2009 " Jurnal Ekonomi Bisnis dan Perbankan. Vol.19

Soetedjo, Soegeng dan Mursida, Safrina, 2014, "Pengaruh Intellectual Capital Terhadap Kinerja Keuangan Pada Perusahaan Perbankan", Prosiding Simposium Nasional Akuntansi, Lombok.

Sugiyono.2007. MetodePenelitian Bisnis.Bandung: Alfabeta 
Suhendah, Rousilita. 2012. "Pengaruh Intellectual Capital Terhadap Profitabilitas, Produktivitas, Dan Penilaina Pasar Pada Perusahaan Yang Go Public Di Indonesia Pada Tahun Tahun 2005-2007’. Simposium Naisonal Akuntansi XV, September 2012.

Sunarsih, N. M. dan Mendra, N. P. Y. 2012."Pengaruh Modal Intelektual Terhadap Nilai Perusahaan dengan Kinerja Keuangan Sebagai Variabel Intervening pada Perusahaan yang Terdaftar di Bursa Efek Indonesia", Simposium Nasional Akuntansi XV. Banjarmasin.

Ulum, Ihyaul. 2013. “iB-VAIC: Model PengukuranKinerja Intellectual Capital Perbankan”. Journal Inferensi. Vol. 7:1.

Ulum,Ihyaul. 2015.IntellectualCapital. Malang: UMM press.

Wijaya, Novia. 2012. Pengaruh Intellectual Capital Terhadap Kinerja Keuangan dan Nilai Pasar Perusahaan Perbankan dengan Metode Value Added Intellectual Capital.Jurnal Bisnis Dan Akuntansi. Vol. 14.No. 3. Hlm. 157-180.

Zuliyati. 2011. "Intellectual CapitalDan Kinerja Keuangan Perusahaan". Dinamika Keuangan dan Perbankan. Vol. 3, No. 1, Hal: $113-125$ 